\title{
Features of University Teachers' Communicative-Speaking Competence
}

\section{Особливості комунікативно-мовленнєвої компетентності викладача вищої школи}

\author{
Olga Korniyaka \\ Dr. in Psychology, \\ Chief Scientific Researcher \\ Kostiuk's Institute of Psychology, \\ National Academy of \\ Pedagogical Sciences \\ 2, Pankivska Str., Kyiv-33, \\ Ukraine, 01033
}

\author{
Ольга Корніяка \\ доктор психологічних наук, \\ головний науковий співробітник
}

E-mail: olga.korniyaka@gmail.com orcid.org/0000-0003-1471-9238

Інститут психологіi

імені Г.С. Костюка НАПН Украӥни

вул. Паньківська, 2, Київ-33, Україна, 01033

Original manuscript received February 17, 2018

Revised manuscript accepted September 10, 2018

\section{ABSTRACT}

The article clarifies the specifics and peculiarities of communicative-speaking competence as the key tool of university teachers' professional communication. The empirical research revealing development of speech communicative means and their influence on professional self-fulfilment is summarised.

Peculiarities of the modern linguistic politics are also analyzed. The article reveals the essence of three present-day specific conflicts in the field of speech communication, which are related to losses by young generations of linguistic landmarks, violations of ethical aspects of speech communication, dependence on cyberspace, disappearance of understood boundaries between reality and virtuality. Teachers' professional work is usually accompanied by professional communication, determined by work goals and providing speechmediated interactions of communicating actors at professional task solving. This is the main means of teachers' work that cannot be replaced by some 
other means and practical activities cannot be performed without it. As for its content, such communication is connected with goals and objectives of their professional work: professional training of students as future specialists and social actors. By its nature, professional communication is a specific activity: "activity in activity». The key means of its implementation is communicativespeaking competence of communicating actors.

In the broad sense, communicative-speaking competence is specialists' integral ability to use verbal interactions; it is a defining psychological tool for their communicative-speaking activities.

The article states that communicative-speaking competence is a leading constituent in teachers' professional competence because of its importance for social practice and its pedagogical significance for establishing of effective and psychologically equal interactions between teachers and their students. The model of communicative-speech competence, created by us during researching, unites three main groups of skills and abilities: communicative-speaking, social-perceptual and interactive, which are its main structural components. They are characterized by a number of characteristics: they are self-consistent, interdependent and hierarchically organized. As communicative means creating a psychic link between interlocutors, they are of a communicative nature as for their content and form.

Communicative-speaking competence also has three integral characteristics determining quality of university teachers' professional interactions: didactic intention, creative orientation and pedagogical flexibility.

The notion on "professional speaking" or "professional language», proposed by 0.O. Leontiev, means that a teacher possesses thesaurus common with other communicants (a similar system of language, concepts, semantic meanings); has correct, figurative, emotional, stylistically determined speech; corresponding facial expressions, gesticulation, kinetics; numerous verbal and non-verbal strategies and tactics, united in the communicative aspect of interactions.

Such "professional language» of a specialist in science and education means professional interactions between teachers and students and it is implemented as an intellectual creative activity associated with "intellectual» communication and including "emotional intelligence». "Intellectual» verbal communication within the educational process means economical, but complete and systematic, transfer of knowledge from its carriers to future specialists.

The performed research has determined regularities and peculiarities of communicative-speaking competence of professionals in sociological sciences depending on a number of objective and subjective factors: specialists' ages, their personality, general and special education, compulsory nature of interactions, constant training, a degree of taking into account of modern requirements to a specific profession and, finally, a type of their leading activity. 
Key words: professional and communicative-speaking competence, verbal communication, intellectual communication, communicative-speaking, socialperceptual and interactive abilities, specialists in science and education.

\section{Вступ}

Сучасний світ $з$ характерними для нього процесами бі-, полі-, транслінгвізму i транскультуралізму поступово перетворився на суспільство глобальних інформаційних комунікацій. В цих умовах відбувається невпинне примноження сфер комунікації, різке поглиблення включення людини в суспільні зв'язки і відносини, постійне ускладнення iï соціальних та професійних функцій, що 3 необхідністю супроводжується «живим» спілкуванням, міжособистісною взаємодією. Під впливом цих чинників сучасна людина має посилювати інтенсивність своєї комунікативної діяльності як невід'ємної складової будь-якої професійної діяльності й поглиблювати якість визначального засобу іiі здійснення - комунікативно-мовленнєвої компетентності - для налагодження психологічно комфортного комунікативного зв'язку 3 іншими людьми 3 метою успішного розв'язання особистих і фахових завдань.

У зв'язку 3 цим перед викладачем як представником комунікативного типу професій i як однією 3 ключових постатей у фаховій підготовці майбутніх професіоналів постає актуальне завдання - надати новим поколінням соціальних суб'єктів компетентну допомогу в опануванні та примноженні нагромаджених людством матеріальних та духовних цінностей; освоєнні комунікативно-мовленнєвих засобів міжособистісної взаємодії як особистісної форми суспільних відносин; становленні та розвитку їх особистості й професіоналізму: засвоєнні нових алгоритмів розв'язання професійних завдань, підвищенні креативності та творчості в діяльності i, зрештою, в успішному самоздійсненні в професії відповідно до нових соціальних тенденцій (OrgovanyiGajdos, 2016). I саме компетентність у мовленнєвій комунікації виступає чи не найважливішим психологічним інструментом досягнення соціального та професійного ефекту цим фахівцем.

Відтак, мета статті - 3'ясування змістової специфіки й особливостей комунікативно-мовленнєвої компетентності викладача 
вищої школи, висвітлення результатів емпіричного дослідження розвитку засобів мовленнєвої комунікації та впливу цих засобів на його самоздійснення у просторі професії.

\section{Методи та методики дослідження}

3 метою з'ясування значення вербального спілкування й особливостей головного засобу його реалізації - комунікативномовленнєвої компетентності та іiі складових - для ефективного здійснення викладачем вищої школи своєї професійної діяльності в психологічному дослідженні використовувалися такі наукові методи, як аналіз і синтез, упорядкування i систематизація теоретичного матеріалу.

В емпіричному дослідженні взяли участь 80 респондентів викладачів кількох університетів України. Дослідження тривало протягом 2016-2017 років. Було використано такі психодіагностичні методи: методику «Діагностика комунікативної компетентності у сфері ділового спілкування» А.Г. Самохвалової, методику «Діагностика перцептивно-інтерактивної компетентності» (модифікований варіант М.П. Фетискіна), тести - «Вміння викладати свої думки» і «Вміння слухати», анкету «Невербальна виразність педагога» О.А. Петрової, а також експертну оцінку сформованості у викладачів професійної компетентності та іï складових. До того застосовано розроблений О.М. Кокуном «Опитувальник професійного самоздійснення», призначений для з'ясування загального рівня професійного самоздійснення фахівця і визначення ступеня вираження окремих його показників (Кокун, 2012; Литвинцева, 1994; Петрова, 1998; Самохвалова, 2012; Фетискин, 2002). 3'ясування провідних чинників професійного самоздійснення викладачів здійснювалося через опрацювання емпіричних даних за допомогою регресійного аналізу.

\section{Теоретичний аналіз проблеми}

Процес професійної діяльності викладача визначають такі умови, як швидко змінювана соціально-економічна ситуація, пріоритетні напрямки освітнього розвитку й реформування професійно-освітньої практики тощо. Звідси головним завданням викладацької діяльності стало досягнення професійно-орієнтованої освіченості, навчально-професійного розвитку і виховання 
професійно відповідальної особистості майбутнього фахівця соціального об'єкта його праці. Тому в основі діяльності викладача, крім грунтовної психолого-педагогічної підготовки, має бути i науково обгрунтована система спеціальних його знань і вмінь та неабиякий досвід здійснення мовленнєвої комунікації. А головним мотивом цього професіонала $є$ самореалізація та самоздійснення у просторі професії.

Як відомо, структура професійної діяльності фахівця освітньонаукової сфери має складний характер i охоплює принаймні такі взаємопов'язані види діяльності: педагогічну, когнітивну, комунікативну, наукову, методичну тощо. Вона характеризується низкою ознак: педагогічна, когнітивна, наукова, соціальна, комунікативно-мовленнєва, методична та ін. (див. табл. 1).

Таблиця 1. Психологічні та психолінгвістичні ознаки суб'єкта науково-педагогічної діяльності

Ознаки 3 Змістові показники

Педагогічні Усвідомлення своєї соціальної ролі, своїх цілей та завдань, власних можливостей; «стартові» компетентності (загальні гуманістичні знання, особистісна культура, інтелектуальні вміння); професійні знання, вміння i навички; професійно змістове педагогічне мовлення (передбачає аналіз і систематизацію інформації, вміння iii пояснювати i цілеспрямовано передавати, несуперечливість відомостей, а також професійно виважені чіткість, темп й інтонація); володіння невербальними прийомами впливу (міміка, жести, поза, зовнішній вигляд); знання своїх здібностей й усвідомлення своїх можливостей у різних професійних ситуаціях; здатність орієнтуватися й орієнтувати у великій кількості багатопланової інформації; ціннісна орієнтованість; володіння нормами професійної етики; емоційна стійкість (стресостійкість).

Комунікативно- Комунікативно-мовленнєва компетентність, розвиненість вербальних мовленнсві навичок діалогічної взаємодії, здатність справляти вплив на партнера зі спілкування (вміння слухати і чути, володіння ефективною тактикою переконання іншої людини, вміння розв'язувати конфлікти); морально-комунікативні якості (ввічливість, тактовність, повага до іншої людини, емпатійність тощо); психологічна i соціальна компетентність, здатність до самопрезентації, створення іміджу; емоційно-вольова регуляція; чутливість до суспільних змін та нововведень; організаційні здібності, вміння координувати свої дії та узгоджувати рішення $з$ діяльністю колег і студентів. 
Наукові

Методичні
Сильна пізнавальна мотивація; пізнавальна активність (знання, інформованість, досвід); розвиненість сприймання i мислення, нестандартне творче мислення (інтелектуальна творчість), креативність; стійкість уваги, спроможної до розподілу та переключення; когнітивні, мнемічні, перцептивні, соціальноперцептивні, комунікативні професійно важливі якості; рефлексивна позиція; вміння проектувати і реалізувати наукові плани; здатність передбачати i моделювати варіанти можливих результатів (прогностичні вміння); вміння підготувати (збір інформації) i провести емпіричне дослідження.

Здатність зробити доступною для слухачів (читачів) професійно важливу інформацію; вміння виділити головне в предметі інтересу, прагнення до постійного ознайомлення 3 новими методами $\mathrm{i}$ прийомами педагогічної діяльності; здатність вдосконалювати свій професіоналізм через втілення найновіших методичних досягнень у педагогічну практику тощо.

Професійну діяльність викладача супроводжує зазвичай професійне спілкування, яке зумовлене іiі цілями і забезпечує взаємодію іiі суб'єктів у процесі розв'язання професійних завдань. Зауважимо, що у разі педагогічної взаємодії йдеться не просто про комунікацію, властиву і технічним системам, і взаємодії людини 3 машиною, а про міжособистісну взаємодію, опосередковану мовленням. Тобто мається на увазі процес спілкування, що являє собою «зв'язок між людьми, що приводить до виникнення взаємного психічного контакту, який виявляється в передаванні партнеру зі спілкування інформації (вербальної і невербальної) i має на меті встановлення взаєморозуміння і взаємопереживання» (Ильин, 2008: 205).

Спілкування є головним засобом діяльності викладача: його не можна замінити якимись іншими засобами і без нього практичну діяльність неможливо виконати. У змістовому плані воно пов'язане 3 цілями та завданнями професійної діяльності цього професіонала: навчально-професійною підготовкою студентів як майбутніх фахівців та соціальних суб'єктів. За своїм характером професійне спілкування $є$ специфічним видом діяльності, або «діяльністю у діяльності» - іншими словами, комунікативною діяльністю. Викладач вищої школи здійснює комунікативну діяльність у всіх сферах своєї роботи: дидактичній, виховній, методичній, технологічній, організаційній тощо - у формі педагогічного мовлення, що відбувається на лекціях, семінарах, практичних 
заняттях, під час консультацій, індивідуальних та групових бесід, групової дискусії, ділових ігор, тренінгів та ін. і залежить від потреб тих, хто навчається.

Тим часом складна за своїм характером і науково-педагогічна по суті професійна діяльність викладача вищого освітнього закладу вимагає від свого суб'єкта компетентності у просторі професії професійної компетентності (опорні знання і базові вміння). Остання має об’єднувати у своєму складі такі ключові компетентності: педагогічну, психологічну, комунікативну, мовленнєву, інформаційну, полікультурну, соціальну, технологічну, самоосвітню, креативну i, зрозуміло, компетентність особистісного самовдосконалення. Домінуючу позицію у складно організованій структурі професійної компетентності викладача займає комунікативно-мовленнєва компетентність через свою соціально-практичну обумовленість i педагогічно-комунікативну значущість для ефективної взаємодії та налагодження суб'єкт-суб'єктних (психологічно рівноправних) відносин між педагогом і студентами.

В широкому розумінні комунікативно-мовленнєва компетентність - це інтегральна здатність фахівця до вербального спілкування, його ключовий засіб. При цьому мовленнєва компетентність суб'єкта комунікації виступає невід'ємною складовою його комунікативної компетентності, реалізуючись у процесі мовлення, мовленнєвого спілкування. Конкретизуючи зміст компетентності у спілкуванні, розглядаємо комунікативномовленнєву компетентність як складно організоване, внутрішньо суперечливе поєднання комунікативних $i$ мовленнєвих знань та вмінь, щзо відображають цілі та результати здійснюваной суб'єктом комунікативної $і$ мовленнєвої діяльності. Це психологічний інструмент, використовуваний фахівцем у процесі діяльності, спілкування і професійного самоздійснення. Підгрунтям у розвитку комунікативно-мовленнєвої компетентності виступають «стартові компетентності», до яких психологи відносять загальні гуманістичні знання, особистісну культуру й інтелектуальні вміння, що стають вихідною точкою у формуванні іiі складових. Ця компетентність визначається великою мірою особистісними якостями та властивостями, ціннісно-смисловими настановленнями, комунікативною спрямованістю i культурою вербального спілкування суб’єкта. 
Створена нами у процесі дослідження модель комунікативномовленнєвої компетентності об'єднує у своєму складі три головних групи вмінь, або здатностей: комунікативно-мовленнєву, сочіальноперцептивну й інтерактивну, що є іï основними структурними складовими (компетентностями). Їм властива низка таких характеристик:

- самостійні (кожна 3 них $є$ унікальним додатком до професійних вмінь);

- взаємозалежні (кожна певною мірою пов'язана 3 іншими);

- ієрархічно організовані (кожна існує завдяки наявності попередньої).

Ці структурні компоненти реалізуються через сукупність мовленнєвих, зображувальних, символічних і кінестетичних засобів суб'єкта спілкування. Визначальна роль у цьому процесі належить мовленню, вивченням якого займалася ще антична риторика. Мовлення, або мовна діяльність, є особливою психічною діяльністю суб'єкта спілкування за допомогою мови. Це «мова в дії», що зумов-люється певною метою, має своє специфічне вираження в конкретних ситуаціях і втілюється в таких основних формах, як говоріння, слухання, писання та читання.

Свою здатність говоріння людина реалізує в процесі мовленнєвого спілкування завдяки певним психічним процесам та мовленнєвим механізмам. При цьому найпростішою одиницею такого спілкування виступає мовленнєве висловлювання, яке i за змістом, і за формою має комунікативний характер, слугуючи засобом спілкування - психічного зв'язку між комунікантами. Аналізуючи мовленнєву діяльність, О.О. Леонтьєв (2007) у свій час наголошував, що кожний iї конкретний акт «починається мотивом та плануванням і завершується результатом, досягненням певної мети». Згідно з його позицією, внутрішньою стороною мовлення $\epsilon$ процеси смислопородження: програмування, планування і контролю за комунікативно-мовленнєвою діяльністю - i смисловираження, або утворення мовлення (зовнішня, моторна сторона): висловлення своїх думок; спроможність вільно (дохідливо, виразно) оперувати усним і письмовим висловлюванням.

Мовлення - важливий інструмент у діяльності викладача. Виступаючи як «засіб конкретизації спілкування» (Бабич, 1990) в нашому випадку педагогічного спілкування, мовленнєвий процес 
безпосередньо пов'язаний із започаткованим О.О. Леонтьєвим (2007) поняттям «професійного мовлення», або «мови професії». Остання передбачає наявність у викладача спільного 3 іншим комунікантом тезаурусу (схожої системи мови, понять, смислових значень); правильного, образного, емоційного, стилістично визначеного мовлення; відповідної міміки, жестикуляції, кінетики; численних вербальних та невербальних стратегій і тактик, що об'єднуються у комунікативному аспекті спілкування.

«Мова» професії фахівця науково-педагогічного профілю являє собою професійно-мовленнєве спілкування між викладачем і студентами і реалізується як інтелектуальна творча діяльність, пов'язана 3 «інтелектуальною» комунікацією, а в іiі складі «емоційним інтелектом». Забезпечення «інтелектуальної» комунікації в межах освітнього процесу передбачає, на думку дослідників (Старовойтенко, 2007), економне, але повне і системне, передавання знання від його носія тим спеціалістам, у тому числі майбутнім, 3 ким він професійно взаємодіє. До того і досі в центрі уваги професійного мовлення викладача такі вимоги до мовлення, про які йдеться 3 давніх часів: переконливість, граматична правильність, виразність і зрозумілість.

Сформованість у викладача мовленнєвої компетентності передбачає розуміння сутності і специфіки професійного мовлення, знання закономірностей i механізмів мовленнєво-мисленнєвої діяльності, врахування вікових можливостей мовленнєвого розуміння i, зрозуміло, культуру мовлення.

Комунікативно-мовленнєва компетентність має також три інтегральних характеристики, що визначать якість професійного спілкування викладача вищої школи: дидактичну інтенцію, креативну спрямованість і педагогічну гнучкість.

А відповідно до нового підходу до мовлення сучасної психолінгвістики, мова розглядається як «засіб актуалізації ментальних процесів», що забезпечують мовленнєву комунікацію. А оскільки мова $є$ найважливішою частиною суспільної культури, то важливою проблемою стає збереження статусу науковоосвітнього мовлення як засобу обміну інформацією і досягнення взаєморозуміння між різними представниками суспільства. Разом 3 тим психолінгвісти відзначають, що в міру нагромадження досвіду проживання в умовах реформ різко зросла чутливість до 
мовного питання: рідна мова усвідомлюється і привласнюється як знаряддя ідентифікації молодого покоління. А.В. Вдовиченко показав (XXV Міжнародна конференція «Математика. Комп’ютер. Освіта»: Дубна, 2018), що поняття «мова науки» розглядається на фоні комунікативної (семіотичної) дії - теоретичної новації, що закономірно випливає з розвитку лінгвістичної теорії (цит. по: Пильгун, 2018). Крім того, згідно з семіотичною теорією D. Hymes, J. Pride \& J. Holmes (1972), має місце співвідношення суб'єктивного й об'єктивного у процесі комунікації, коли об'єктивна реальність опосередковується завдяки попередній суб'єктивній інтерпретації знаків, а відтак, завдяки їх перетворенню на «семіотичну» реальність. У цих умовах питання мовної політики в освіті і науці мають розв'язуватися, на думку вчених, на грунті гуманітарної експертизи, здатної оцінити можливі наслідки реформування в галузі мови (матеріальних знаків).

Поза тим результатом професійної діяльності викладача $€$ передусім інформування студентів 3 певної галузі знань, якому передує мовленнєво-мисленнєва діяльність, його вміння відстежити та зібрати потрібну інформацію, опрацювати іiі і зуміти в оригінальній формі передати iï студентам. Як носій фахового знання він має прагнути до відтворення реальної картини світу, яка виступає як заснована на досвіді, перцепції та рефлексії «континуальна система смислів» (Bennet, 1998), що їх він транслює через мовлення об'єктам своєї праці. Звідси про сформованість комунікативно-мовленнєвої (і мовної) компетентності свідчать здатність до отримання інформації, адекватного розуміння iï смислу та безпомилкового передавання партнерові зі спілкування, вміння викладача орієн-туватися в конкретній педагогічній ситуації, його здатність «читати за обличчям», визначати психологічну сутність та емоційний стан іншої людини за їі мовленням.

Нагадаємо також, що професіонали цього типу змушені встановлювати численні комунікативні контакти 3 різними (за віком, освітою, статусом, статтю тощо) людьми, вони мають емоційно включатися у процес фахового спілкування, повинні правильно організовувати взаємини у системі «людина - людина». Це пов'язане 3 оцінкою і розумінням партнерів зі спілкування, здатністю до співпереживання, вмінням розуміти настрій інших людей, 3 високою чутливістю стосовно співрозмовника і вмінням 
контролювати власні почуття та емоції. Всі ці вміння поєднуються в межах перцеептивного аспекта спілкування.

У зв’язку зі сказаним зауважимо: професія викладача - одна 3 найбільш комунікабельних й емоційно насичених професій, коли спілкування 3 іншими людьми часто пов'язане 3 емоційним стресом, внаслідок чого можуть мати місце емоційне виснаження та зниження професійної ефективності - в тому числі, виникнення складнощів у мовленні (Skaalvik \& Skaalvik, 2017).

Тим часом для розв'язання специфічних комунікативних завдань: передавання інформації, сприймання комунікантами один одного, взаємооцінки, взаємодії, взаємовпливу, організації та управління діяльністю тощо - у професійному спілкуванні фахівців-соціономів, у тому числі університетських викладачів, мають бути наявні такі складові: здатність встановлювати i підтримувати необхідні контакти 3 людьми, позитивне ставлення до оточуючих, вміння обирати адекватні педагогічній ситуації комунікативно-мовленнєві засоби міжособистісної взаємодії, висока здатність до співпраці, вміння виконувати певні соціальні ролі у колективі, вміння улагоджувати розбіжності та конфлікти, вміння співробітничати та працювати 3 групою (у групі), зосередженість на стимулюванні вербальної комунікації, симетричне включення в неї обох партнерів зі спілкування, прагнення до взаєморозуміння та взаємопереживання тощо. Названі нами вміння об'єднує інтерактивний аспект спілкування (Психология общения, 2011).

Специфіка мовлення представника будь-якої професії детермінується виконуваними ним функціями. На думку психологів, діяльність педагога, а відтак, i викладача, передбачає виконання таких функцій: інформаційної, розвиткової, мобілізаційної, орієнтуючої, конструктивної, комунікативної, організаційної, дослідницької (Психология общения, 2011). Всі ці функції реалізуються передусім через мовлення i можуть розглядатися в якості його функцій (див. табл. 1).

А опертя на теоретичні положення психолінгвістичної науки дає змогу говорити також про виконання викладачем своєрідної «посередницької» функції у процесі вербальної комунікації - між адресантом (автором інтерпретованої інформації) i адресатом (студентами як отримувачами цієї інформації). При цьому мовленнєві якості особистості викладача як інтерпретатора, а 
відтак, посередника в передаванні знання студентам визначають ефективність його педагогічної, комунікативно-мовленнєвої за характером, діяльності. Мовленнєве посередництво реалізується через такі мовленнєві вміння: 1) вміння говорити (виразно, переконливо і дохідливо): вміння орієнтуватися в певній предметній галузі, здатність зробити інформацію доступною для менталітету комунікантів, вміння правильно сформулювати сутність проблеми, здатність до переструктурування змісту, вміння виділяти головне в предметі інтересу, вміння ставити запитання і давати відповіді на запитання інших комунікантів і 2) вміння слухати - і чути сказане співрозмовником, тобто вміння налагодити з ним емоційний зворотний зв'язок під час обміну інформацією, й ін.

Поза тим під час спілкування, педагогічної взаємодії, відбувається різка зміна видів нервової діяльності індивіда. При цьому нейрони мозку активно навантажені: вони забезпечують створення фахівцем - озброєним комунікативно-мовленнєвою компетентністю як інтегрованою здатністю до спілкування - нових схем та моделей комунікації, розвиток пізнавального ставлення до навчальної ситуації та навколишнього світу, розв'язання актуальних проблем і конфліктів, вироблення ресурсу соціальної адаптації i взаємообміну інформацією. Адже природою закладено так, що значна частина мисленнєвих i комунікативно-мовленнєвих здатностей людини призначена для підтримання саме «живого» спілкування 3 іншою людиною. В цей час людський мозок, за твердженням одного 3 провідних світових нейробіологів Філіпа Хайтовича, збагачується (або позбавляється - при «урізанні» спілкування) великою часткою інформації, на отримання й опрацювання якої він «заточений». У випадку інтенсивного професійного спілкування викладача зі студентами - в умовах підтримання високої працездатності задля розв'язання педагогічних завдань - його адаптаційні та креативні ресурси і можливості професійного самоздійснення примножуються (Корніяка, 2016).

\section{Дискусії}

У зв'язку зі сказаним можна говорити принаймні про три специфічних конфлікти сьогодення у сфері мовленнєвої комунікації, пов'язані 3 втратою молодим поколінням мовних орієнтирів, порушеннями в етичному аспекті мовленнєвої комунікації; з певним 
погіршенням знання рідної мови в умовах білінгвізму, що веде до підміни культурних архетипів свідомості й руйнування культурної ідентичності, та його залежністю від кіберпростору, зникненням розуміння межі між реальністю і віртуальністю.

По-перше, це стосується конфлікту між класичними духовними цุінностями, що формувалися історично тривалий час у тісній взаємодії з реальним життям і є смисло- та культуротворними, й інтернет-«иінностями», що встановлюються «власниками мережі» хаотично, безсистемно, незалежно від перевірки реальністю i спрямовані переважно на маніпуляцію свідомістю людини. Проте саме вплив «мережних цінностей» на умонастрої людей набагато сильніший, ніж вплив реальних цінностей (Шалагінов, 2016). Розуміючи це, сучасний викладач у своїй діяльності повинен віднаходити такі засоби, які давали б змогу нейтралізувати «віртуальну» загрозу реальності: відновити довіру до своїх поглядів i вербалізованих ним класичних істин. А його психологічний вплив має перевершувати вплив сумнівних постулатів: підносити авторитет як носія підсиленої доказами об'єктивної інформації, порадника в життєвих питаннях, творця нових культурних i моральних цінностей. На жаль, ще не існує дієвих методів та методик протидії «чужому впливу» через надзвичайну складність і непередбачуваність внутрішнього світу людини, іiі психологічної складової. Тому повсякчасне застосування університетським викладачем засобів - передусім вербальних - зміцнення сили свого морального авторитету і довіри слухача до мовленого ним не тільки визначатимуть ефективність його професійно-педагогічної взаємодії зі студентами, а й сприятимуть взаємній рефлексії, взаємоповазі та емоційній регуляції їх мовленнєвого спілкування.

По-друге, психолінгвісти 3 різних країн твердять, що глобальний перехід на англійську мову у сфері гуманітарних наук, що набирає обертів, може призвести до безповоротних для національних культур наслідків, а в соціумі - до «протестних рухів аж до украй агресивних». Ситуація має ще складніший характер в умовах полілінгвізму в українському суспільстві і потребує свого невідкладного вирішення.

На подібні згубні для суспільства наслідки вказує, зокрема, Ю.Д. Нечипоренко (Руський ПЕН-центр, 2018), зауважуючи, що «молоді дослідники часом не встигають навчитися думати 
i писати рідною мовою, як їм пропонують перейти на чужу. В результаті понятійна база науки стає неповноцінною, творчий розвиток вченого і традиція освіти рідною мовою перериваються. Як репутація вітчизняних вчених, так і престиж країни в цій ситуації різко падають» (цит. по: Пильгун, 2018). У зв’язку з цим Н.В. Уфімцева (Інститут мовознавства РАН, 2018) застерігає, що вимушений білінгвізм при стрімкому погіршенні знання рідної мови веде до серйозних наслідків: до підміни культурних архетипів свідомості, до руйнування культури та культурної ідентичності (цит. по: Пильгун, 2018).

На нашу думку, вирішення мовної проблеми потребує масштабної дискусії з приводу надавання пріоритету в опануванні рідної мови та підтримання ідеї розширення простору кирилиці i, зрозуміло, професійної участі в цьому обговоренні фахівців освітньо-наукової сфери.

По-третє, наукове співтовариство дедалі голосніше заявляє про кризу «самоздійснення» та появу так званого «покоління Гугл», що потребує особливих освіти і виховання. В контексті останньої йдеться про наявність кризи і у сфері спілкування, під впливом якого відбувається становлення особистості. Це передусім стосується порушень в етичному аспекті мовленнєвої комунікації, надмірного переважання суб'єкт-об'єктного стилю міжособистісної взаємодії над суб'єкт-суб'єктним. У зв'язку з цим слушною $\epsilon$ думка О. Чувакіна, згідно 3 якою один 3 учасників наділяє себе правами суб'єкта мисленнєво-комунікативної діяльності, в іншому ж бачить лише об'єкт (авторський сайт: olegchuvakin, 2010). Така психологічна нерівноправність учасників у комунікативній мисленнєво-мовленнєвій - діяльності не відповідає принципам устрою комунікативного суспільства взагалі i, зокрема, засадам педагогічної комунікації. Як наслідок - «зникає конкуренція у сфері смислів», що негативно позначається на особистісному та комунікативному розвитку сучасного фахівця. У стані кризи особистість не має відповідної реаліям комунікативно-мовленнєвої поведінки і не володіє повноцінно іiі інструментом - комунікативномовленнєвою компетентністю, а отже, стає неефективною як у просторі професії, так і в міжособистісному спілкуванні.

Останній конфлікт, на нашу думку, є вельми серйозним i вимагає негайної його оцінки фахівцями. Тут провідну роль 
мають відігравати сучасні фахівці саме науково-педагогічного профілю як особливо інтелектуально i морально чутливі - адже вони раніше від інших можуть уловлювати результати суспільних змін і нововведень, а їх реальним життєвим потенціалом виступає діалогічна комунікація 3 іншими людьми. А оскільки викладачеві притаманна активна позиція в професійній дільності, то його мовленнєва комунікація 3 суспільством, нетрадиційний погляд на вирішення проблеми, безумовно, викличуть відповідний резонанс i справлятимуть вплив на думки та дії членів соціуму.

Зі сказаного випливає, що суб’єкт науково-педагогічної діяльності має володіти, крім традиційно вичленовуваних дослідниками фахових знань i навичок, спеціальних здібностей i розвинених професійно важливих якостей, ще й соціально значущиим, морально-комунікативними, якостями. Адже він характеризується трьома пріоритетними началами - професійним (інтелектуально-творчим), етичним і рефлексивним у їхній взаємодії одне 3 одним (Shalahinov, 2016), що концентровано виражають досягнутий ним стан особистісного і професійного самоздійснення.

\section{Обговорення результатів емпіричного дослідження}

Емпіричне дослідження показало, що спостерігається зниження розвитку комунікативно-мовленнєвої компетентності у сфері ділового спілкування та окремих ї складових - зокрема, мотиваційних спонук до педагогічного спілкування та деяких інструментальних здатностей $(\mathrm{p} \leq 0,05-0,01)$ у викладачів вищої школи в міру дорослішання - 40 років i старші. Зафіксовано також недостатність розвитку у цих фахівців вміння викладати свої думки, вміння слухати і перц̧ептивно-невербальних засобів, що належать до визначальних складових комунікативномовленнєвої компетентності, для безпроблемного розв'язання завдань професійної самореалізації цих фахівців (Корніяка, 2015). До цього, певно, призводять комунікативні деформації (внаслідок надмірної «ідентифікації» особистості з професією) і послаблення психологічної готовності (або їі відсутність) до нових професійних, у тому числі комунікативних, звершень. Крім того, того в міру дорослішання i ймовірного посилення професійного навантаження може мати місце виснаження емоційних ресурсів: спустошеність, 
пригніченість, закритість, авторитарність тощо, які ведуть до «професійно-комунікативного вигорання», зменшення ролі емоційної, рефлексивної і комунікативної домінант у структурах суб'єктів освіти і науки. Все це актуалізує потребу в їх постійному професійно-комунікативному вдосконаленні 3 метою успішного самоздійснення у просторі професії.

3 урахуванням 3'ясованих в емпіричному дослідженні психологічних закономірностей та особливостей професійного самоздійснення викладача ВН3, а також визначальних чинників впливу на цей процес та його результати, окреслено основні напрямки, засоби та найважливіші завдання розв'язання проблеми психологічного забезпечення високої ефективності його професійної діяльності. Статистичне опрацювання емпіричних даних за допомогою регресійного аналізу показало, що серед найбільш виражених предикторів досягнення викладачем вищої школи високого рівня самоздійснення у професії вирішальне значення мають комунікативні (в тому числі мовленнєві) чинники, що зумовлено специфікою його професійної діяльності, здійснюваної у формі науково-педагогічного спілкування. Зокрема, серед прогностичних чинників впливу на процес i результат досягнення викладачем внутрішньопрофесійного самоздійснення частка комунікативномовленнєвих чинників дорівнює $64,3 \%$; зовнішньопрофесійне ж самоздійснення визначають $44 \%$ цих чинників.

Відтак, до провідних чинників впливу на процес самоздійснення в просторі професії належить передусім комунікативно-мовленнєва компетентність, що є ключовою складовою професійної компетентності - поряд з інформаційною, креативною, педагогічною та самоосвітньою компетентностями. Вона $є$ визначальною здатністю викладача до спілкування i передбачає акцент на таких своїх складових:

а) мотиваційному критерії - для посилення самовдосконалення у сфері ділового спілкування, поглиблення мотиву подолання комунікативних труднощів й інтересу до сфери ділового спілкування; когнітивному критерії - для опанування індивідуальних комунікативних особливостей, побудови ефективних комунікативних програм, забезпечення рефлексії ділових комунікацій; інструментальному критерії - для актуалізації 
індивідуально-своєрідної системи комунікативних вмінь, розвитку креативності й досягнення адекватності у сфері ділового спілкування (критерії виділено за методикою А.Г. Самохвалової (2012);

б) мовленнєвій компетентності як здатності до планування та програмування i дохідливого висловлення своїх думок, як спроможності вільно оперувати своїм мовленням під час педагогічної взаємодії;

в) невербальній (педагогічній) виразності мовленнєвої комунікації: ii посиленні через оптимальний темп зміни формальнодинамічних параметрів (міміка, жести, погляд, вираз обличчя) невербальної поведінки $\mathrm{i}$ розвиток здатності до управління та рефлексії в педагогічному спілкуванні тощо.

У зв'язку з цим зауважимо, що до найпоширеніших моделей особистісної зміни, актуальних у плані комунікативно-мовленнєвого вдосконалення фахівця, належить розвиток особистості через взаємодію, тобто шляхом набуття нового досвіду комунікації i перевірки у ході комунікативної та мовленнєвої діяльності ефективності набутих раніше зв'язків спілкування i засобів його реалізації. При цьому на початкових етапах становлення фахівця розвиток комунікативно-мовленнєвої компетентності проходить шлях від рівня інтуїтивного освоєння суб'єктом діяльності тієї чи тієї здатності - комунікативно-мовленнєвої, соціально-перцептивної чи інтерактивної - до рівня свідомого ї̈ опанування. Тим часом на різних етапах професійної зрілості - професіоналізації і досягнення професійної майстерності - використання цих здатностей у взаємодії та їх розвиток мають зазвичай усвідомлений характер. Це пов'язано, по-перше, 3 потребою розв'язання конкретних фахових завдань; по-друге, з психологічним розвитком особистості, соціальною та професійною необхідністю іiі комунікативномовленнєвого самовдосконалення.

Крім того, психологічне дослідження показало, що закономірності та особливості розвитку комунікативно-мовленнєвої компетентності на всіх етапах становлення фахівця визначаються низкою ще й таких об'єктивних і суб'єктивних чинників: віком фахівця; розвитком його особистості; загальною $i$ спеціальною підготовленістю; обов'язковістю спілкування: налагодження постійного формального й емоційно насиченого контакту 3 іншими 
людьми, включення особистості у взаємини, прилучення до «фонду спільних знань» і соціальних ігор (додержання норм, правил, ролей і статусів); постійним тренуванням (навантаженням нейронної системи мозку) у «правильному», відповідному професійній діяльності, комунікативно-мовленнєвому середовищі; ступенем урахування сучасних вимог до конкретної професії - особливо до професій соціономічного профілю, що передбачають більш тісне i різноманітне спілкування, інтенсивний обмін інформацією 3 іншими людьми та ставленням до неї i, нарешті, типом провідної діяльності їі суб'єкта.

\section{Висновки}

Процес мовленнєвої комунікації в системі «викладач студенти», що реалізується через сукупність мовленнєвих, зображувальних, символічних i кінестетичних засобів, сприяє розвитку потреб та мотивів їх діяльності, озброює знаннями, вміннями та навичками. Викладач відіграє ключову роль у цьому процесі, послуговуючись сформованою у професійній діяльності комунікативно-мовленнєвою компетентністю й орієнтуючись на потреби того, кому він транслює знання. При цьому він не тільки справляє вплив, а й зазнає зворотнього впливу - в результаті відбувається актуалізація емоцій, експресивного змісту мовленого, його засвоєння студентами.

Для здійснення цілеспрямованого перетворення у свідомості та поведінці учасників педагогічної взаємодії фахівець науковопедагогічного профілю має повсякчас урізноманітнювати комунікативно-мовленнєві засоби свого психологічного впливу: оптимально організовувати вербальну й емоційно насичену інформацію; постійно збагачувати репертуар своїх виражальних засобів - міміку, пантоміміку, лексичну i динамічні сторони мовлення (інтонацію, тембр, ритм, вібратор голосу), що сприятиме успішному вирішенню ним професійних завдань та самоздійсненню у просторі професії.

\section{Література}

Бабич, Н.Д. Основи культури мовлення. Львів : Світ, 1990. С. 11-12.

Иванова, Е.М. Психология профессиональной деятельности. Москва : Персэ, 2011. $336 \mathrm{c}$.

Ильин, Е.П. Мотивация и мотивы. Санкт-Петербург : Питер, 2008. 512 с. 
Кокун, О.М. Життєве та професійне самоздійснення як предмет дослідження сучасної психології. Практична психологія та соиіальна робота. 2013. № 9. C. $1-5$.

Корніяка, О.М. Комунікативна компетентність як визначальний чинник професійного самоздійснення викладача вищої школи. Актуальні проблеми nсихологіï. T. VI: Психофізіологія. Психологія праці. Експериментальна психологія. Київ : ДП «Інформ.-аналіт. агентство», 2016. Вип. 16. С. 82-92.

Корніяка, О.М. Комунікативний аспект професійного самоздійснення викладача вищої школи. Актуальні проблеми психологї. Т. VI: Психофізіологія. Психологія праці. Експериментальна психологія. Київ : ДП «Інформ.-аналіт. агентство», 2015. Вип. 15. С. 71-82.

Леонтьев, А.А. Психология общения: Москва : Смысл ; Издательский центр «Академия», 2007. 368 с.

Литвинцева, Н.А. Женская психология. Москва : АО «Бизнес-школа «Интелсинтез», 1994.

Петрова, Е.А. Жести в педагогическом процессе. Москва : Московское городское педагогическое общество, 1998. 222 с.

Пильгун, М.А. Русская научная речь: статус и перспективы развития. Bonpocbl психолингвистики. 2018. № 1(35). С. 169-172.

Психологические основы профессиональной деятельности: хрестоматия / Сост. В.А. Бодров. Москва : ПЕР СЭ ; Логос, 2007. 855 с.

Психология общения. Энциклопедический словарь. А.А. Бодалев (ред.). Москва : Изд-во «Когито-Центр», 2011. 600 с.

Психологія праці. Експериментальна психологія. Київ : ДП «Інформ.-аналіт. агентство», 2015. Вип. 15. С. 71-82.

Самохвалова, А.Г. Деловое общение: секреты эффективных коммуникаций. Санкт-Петербург : Речь, 2012.

Старовойтенко, Е.Б. Культурная психология личности. Москва : Академический Проект ; Гаудеамус, 2007. 310 с.

Фетискин, Н.П., Козлов, В.В., Мануйлов, Г.М. Социально-психологическая диагностика развития личности и малых групп. Москва : Изд-во Института Психотерапии, 2002. 490 с.

Шалагінов, Б. Національно-культурний суверенітет та сучасна мережна цивілізація. Всесвіт. 2016. № 7-8. С. 217-218.

Olegchuvakin.ru/wordhappiness. htmI - category/publicism

Bennet, M. (1998). Basic concepts of Intercultural Communication: Selected Readings. Yarmouth.

Hymes, D., Pride, J.B., \& Holmes, J. (1972). On Communicative Competence. In D. Hymes (Ed.). New York : Harmondsworth : Penguin.

Orgovanyi-Gajdos, J. (2016). Main Features of the Training Programme for Teachers' Professional Development on Problem Solving. Teachers' Professional Development on Problem Solving. Sense Publishers, Rotterdam. doi: 10.1007/97894-6300-711-5_3

Skaalvik, E.M., \& S Skaalvik, S. (2017). Still motivated to teach? A study of school context variables stress and job satisfaction among teachers in senior high school. Social Psychology of Education, 20(1), 15-37. doi: 10.1007/s 11218-016-9363-9

Teachers' Professional Development on Problem Solving. Teachers' Professional Development on Problem Solving. Sense Publishers, Rotterdam. doi: 10.1007/97894-6300-711-5_3 


\section{References}

Babych, N.D. (1990). Osnovy kultury movlennia [Bases of culture of speech]. Lviv : Svit [in Ukrainian].

Ylyn, E.P. (2008). Motyvatsyia y motyvy [Motivation and motives]. SanktPeterburh : Pyter [in Russian].

Yvanova, E.M. (2011). Psykholohyia professyonalnoi deiatelnosty [Psychology of professional activity]. Moscow : Perse [in Russian].

Korniiaka, O.M. (2015). Komunikatyvnyi aspekt profesiinoho samozdiisnennia vykladacha vyshchoishkoly [Communicative aspect of professional selffulfilment of teacher of higher school]. Aktualni problemy psykholohii. T. VI: Psykhofiziolohiia. Psykholohiia pratsi. Eksperymentalna psykholohiia - Actual problems of psychology. psychophysiology. Psychology of work. Experimental psychology. (Vol. 6), (pp. 71-82) [in Ukrainian].

Korniiaka, O.M. (2016), Komunikatyvna kompetentnist yak vyznachalnyi chynnyk profesiinoho samozdiisnennia vykladacha vyshchoi shkoly [Communicative competence as determinative of professional self-fulfilment of teacher of higher school]. Aktualni problemy psykholohii. T. VI: Psykhofiziolohiia. Psykholohiia pratsi. Eksperymentalna psykholohiia - Actual problems of psychology. psychophysiology. Psychology of work. Experimental psychology, (Vol. 6), (pp. 16. 82-92) [in Ukrainian].

Kokun, O.M. (2013). Zhyttieve ta profesiine samozdiisnennia yak predmet doslidzhennia suchasnoi psykholohii [Vital and professional self-realization as a subject of study of modern psychology]. Praktychna psykholohiia ta sotsialna robota - Practical psychology and social work, 9, 1-5 [in Ukrainian].

Lytvyntseva, N.A. (1994). Zhenskaia psykholohyia [Women's psychology]. Moscow : AO «Byznes-shkola «Yntel-syntez» [in Russian].

Leontev, A.A. (2007). Psykholohyia obshchenyia [Psychology of communication]. Moscow : Smysl ; Yzdatelskyi tsentr «Akademyia» [in Russian].

Pylhun, M.A. (2018). Russkaia nauchnaia rech: status y perspektyvy razvytyia [Russian scientific speech: status and development prospects]. Voprosy psykholynhvystyky Journal of Psycholinguistics, 1(35), 169-172 [in Russian].

Petrova, E.A. (1998). Zhesty $v$ pedahohycheskom protsesse [Testicity in the pedagogical process]. Moscow : Moskovskoe horodskoe pedahohycheskoe obshchestvo [in Russian].

Samokhvalova, A.H. (2012). Delovoe obshchenye: sekretbl эffektyvnolkh komunykatsyi [Business communication: the secrets of effective communication]. SanktPeterburh : Rech [in Russian].

Psykholohycheskye osnovy professyonalnoi deiatelnosty [Psychological foundations of professional activity] (2007). In V.A. Bodrov (Ed.). Moscow : PER SE ; Lohos [in Russian].

Fetyskyn, N.P., Kozlov, V.V., \& Manuilov, G.M. (2002). Sotsyalno-psykholohycheskaia dyahnostyka razvytyia lychnosty y malykh hrupp [Socio-psychological diagnosis of personality development and small groups]. Moscow : Yzd-vo Ynstytuta Psykhoterapyy [in Russian].

Psykholohyia obshchenyia. Эntsyklopedycheskyi slovar [Psychology of communication. Encyclopedic Dictionary] (2011). In A.A. Bodalev (Ed.). Moscow : Yzd-vo «Kohyto-Tsentr» [in Russian].

Starovoitenko, E.B. (2007). Kulturnaia psykholohyia lychnosty [Cultural psychology of personality]. Moscow : Akademycheskyi Proekt ; Haudeamus [in Russian]. 
Shalahinov, B. (2016). Natsionalno-kulturnyi suverenitet ta suchasna merezhna tsyvilizatsiia [National and cultural sovereignty and modern networkcivilization]. Vsesvit - Universe, 7-8, 217-218 [in Ukrainian].

Bennet, M. (1998). Basic concepts of Intercultural Communication: Selected Readings. Yarmouth.

Hymes, D. (1972). On Communicative Competence. In J.B. Pride \& J. Holmes (Eds.). New York : Harmondsworth : Penguin.

Olegchuvakin.ru/wordhappiness. htmI - category/publicism.

Orgovanyi-Gajdos, J. (2016). Main Features of the Training Programme for Teachers' Professional Development on Problem Solving. Teachers' Professional Development on Problem Solving. Sense Publishers, Rotterdam. doi: 10.1007/97894-6300-711-5_3

Skaalvik, E.M., \& Skaalvik, S. (2017). Still motivated to teach? A study of school context variables stress and job satisfaction among teachers in senior high school. Social Psychology of Education, 20(1), 15-37. doi: 10.1007/s 11218-016-9363-9

\section{АНОТАЦІЯ}

У статті з'ясовано змістову специфіку й особливості комунікативномовленнєвої компетентності як ключового інструмента професійного спілкування викладача вищої школи. Висвітлено результати емпіричного дослідження розвитку засобів мовленнєвої комунікації та їх впливу на процес його самоздійснення у просторі професії.

Проаналізовано також особливості сучасної мовної політики $i$ розкрито сутність трьох специфічних конфліктів сьогодення у сфері мовленнєвої комунікації, пов'язаних з втратою молодим поколінням мовних орієнтирів, порушеннями в етичному аспекті мовленнєвої комунікації, залежністю від кіберпростору, зникненням розуміння межі між реальністю і віртуальністю.

Показано, що професійну діяльність викладача супроводжує зазвичай професійне спілкування, яке зумовлене ії чілями $і$ забезпечує опосередковану мовленням взаємодію ії суб'єктів у процесі розв'язання професійних завдань. Це головний засіб його діяльності, який не можна замінити якимись іншими засобами і без якого практичну діяльність неможливо виконати. У змістовому плані це спілкування пов'язане з цілями та завданнями його професійної діяльності: навчальнопрофесійною підготовкою студентів як майбутніх фахівців та соціальних суб'єктів. За своїм характером професійне спілкування $\epsilon$ специфічним видом діяльності: «діяльністю у діяльності». Ключовим засобом його реалізації виступає комунікативно-мовленнєва компетентність суб'єкта спілкування.

В широкому розумінні

комунікативно-мовленнєва компетентність - це інтегральна здатність фахівця до вербального спілкування, яка виступає визначальним психологічним інструментом здійснення ним комунікативної та мовленнєвої діяльності. 
Наголошується, що домінуючу позицію у складно організованій структурі професійної компетентності викладача займає саме комунікативно-мовленнєва компетентність через свою соціальнопрактичну обумовленість і педагогічно-комунікативну значущість для налагодження ефективної і психологічно рівноправної взаємодії між педагогом і студентами.

Створена нами у процесі дослідження модель комунікативномовленнєвої компетентності об'єднує у своєму складі три головних групи вмінь, або здатностей: комунікативно-мовленнєву, соціальноперцептивну й інтерактивну, що $\epsilon$ ї основними структурними складовими (компетентностями). Їм властива низка характеристик: вони самостійні, взаємозалежні й ієрархічно організовані. Як засобам спілкування - психічного зв'язку між комунікантами - ім притаманний комунікативний характер і за змістом і за формою.

Показано, що комунікативно-мовленнєва компетентність має також три інтегральних характеристики, що визначать якість професійного спілкування викладача вищої школи: дидактичну інтенцію, креативну спрямованість і педагогічну гнучкість.

Започатковане О.О. Леонтьєвим поняття «профресійного мовлення», або "мови професії», передбачає наявність у викладача спільного з іншим комунікантом тезаурусу (схожої системи мови, понять, смислових значень); правильного, образного, емочійного, стилістично визначеного мовлення; відповідної міміки, жестикуляиії, кінетики; численних вербальних та невербальних стратегій і тактик, що об'єднуються у комунікативному аспекті спілкування.

«Мова» професії фохівия науково-педагогічного профілю являє собою професійно-мовленнєве спілкування між викладачем $i$ студентами і реалізується як інтелектуальна творча діяльність, пов'язана з «інтелектуальною» комунікацією, а в ії складі - «емоційним інтелектом». Забезпечення «інтелектуальної» вербальної комунікації в межах освітнього процесу передбачає економне, але повне і системне, передавання знання від його носія майбутнім спеціалістам.

Виокремлено закономірності та особливості розвитку комунікативно-мовленнєвої компетентності професіонала сочіономічного профрілю, що визначаються низкою таких об'єктивних і суб'єктивних чинників: віком фахівия, розвитком його особистості, загальною $і$ спеціальною підготовленістю, обов'язковістю спілкування, постійним тренуванням, ступенем урахування сучасних вимог до конкретної професії $i$, нарешті, типом здійснюваної ним провідної діяльності.

Ключові слова: професійна і комунікативно-мовленнєва компетентність, вербальне спілкування, інтелектуальна комунікація, комунікативномовленнєва, соціально-перцептивна й інтерактивна здатності, фрахівці науково-педагогічного профілю. 
Корнияка Ольга. Особенности коммуникативно-речевой компетентности преподавателя высшей школы

\section{АННОТАЦИЯ}

В статье определены содержательная специфика и особенности коммуникативно-речевой компетентности как ключевого инструмента профессионального общения преподавателя высшей школы. Освещены результаты эмпирического исследования развития средств речевой коммуникации и их влияния на процесс его самоосуществления в пространстве профессии.

Проанализированы особенности языковой политики нашего времени, а также раскрыта сущность трех специфических конфликтов современности в срере речевой коммуникации, связанных с утратой молодым поколением языковых ориентиров, нарушениями в этическом аспекте речевой коммуникации, зависимостью от киберпространства, исчезновением понимания между реальностью и виртуальностью.

Показано, что профессиональную деятельность преподавателя сопровождает, как правило, профессиональное общение, которое обусловлено ее целями и обеспечивает опосредованное речью взаимодействие ее субъектов в прочессе решения профессиональных задач. Это главное средство его деятельности, которое нельзя заменить какими-то другими средствами и без которого практическую деятельность невозможно выполнить. В содержательном плане оно связано с целями и задачами его профессиональной деятельности: учебно-профессиональной подготовкой студентов как будущих специалистов и социальных субъектов. По своему характеру профрессиональное общение является специфическим видом деятельности, или «деятельностью в деятельности». Ключевым средством его реализации выступает коммуникативно-речевая компетентность субъекта общения.

В широком понимании коммуникативно-речевая компетентность - это интегральная способность профессионала $к$ вербальному общению, которая выступает ключевым психологическим инструментом осуществления им коммуникативной и речевой деятельности.

Подчеркивается, что доминирующую позицию в сложно организованной структуре профессиональной компетентности преподавателя занимает именно коммуникативно-речевая компетентность благодаря своей социально-практической обусловленности и педагогической значимости для эффективного и психологически равноправного взаимодействия между педагогом и студентами.

Созданная нами в процессе исследования модель коммуникативноречевой компетентности объединяет в своем составе три главных 
группы умений, или способностей: коммуникативно-речевую, социальноперцептивную й интерактивную, которые выступают ее основными структурными составляющими (компетентностями). Для них характерны такие особенности: они самостоятельны, взаимозависимы и иерархично организованы. Как средствам общения - психической связи между коммуникантами - им присущ коммуникативный характер и по содержанию и по форме.

Показано, что коммуникативно-речевая компетентность имеет также три интегральных характеристики, которые определяют качество профессионального общения преподавателя высшей школы: дидактическую интенцию, креативную направленность и педагогическую гибкость.

Введенное в оборот А.А. Леонтьевым понятие «профессиональной речи», или "языка профессии», предполагает наличие у преподавателя общего с другим коммуникантом тезауруса (похожей системы языка, понятий, смысловых значений); правильной, образной, эмоциональной, стилистически определенной речи; соответствующей мимики, жестикуляции, кинетики; многочисленных вербальних и невербальних стратегий и тактик, которые объединяются в коммуникативном аспекте общения.

«Язык» профрессии специалиста научно-педагогчческого профиля представляет собой профессионально-речевое общение межуу преподавателем и студентами и реализуется как интеллектуальная творческая деятельность, связанная с "интеллектуальной» коммуникацией, а в ее составе - «эмоциональным интеллектом». Обеспечение «интеллектуальной» вербальной коммуникации в образовательном процессе предполагает экономную, но полную и системную передачу знания от его носителя будущим специалистам.

Выявлены закономерности и особенности развития коммуникативно-речевой компетентности специалиста социономического профиля, которые определяются рядом таких объективных и субъективных фракторов: возрастом специалиста, развитием его личности, общей и специальной подготовленностью, обязательностью общения, постоянной тренировкой, степенью учета современных требований к конкретной профессии и, наконеи, типом осуществляемой им ведущей деятельности.

Ключевые слова: профессиональная и коммуникативно-речевая компетентность, вербальное общение, интеллектуальная коммуникация, коммуникативно-речевая, социально-перцептивная и интерактивная способности, специалисты научно-педагогического профиля. 